\title{
Specify Site of Metastasis
}

National Cancer Institute

\section{Source}

National Cancer Institute. Specify Site of Metastasis. NCI Thesaurus. Code C158875.

A request to specify the site of the metastasis. 